\title{
Microsatellites to reveal genetic diversity and to distinguish four mangoes of Tegal District, Central Java, Indonesia
}

\author{
ANNUR HIDAYAT, ENNI SUWARSI RAHAYU, MUHAMMAD ABDULLAH, AMIN RETNONINGSIH \\ Department of Biology, Faculty of Mathematics and Natural Sciences, Universitas Negeri Semarang. Jl. Raya Sekaran, Gunungpati, Semarang City \\ 50229, Central Java, Indonesia. Tel.: +62-24-8508112, `email: aminretnoningsih2016@mail.unnes.ac.id
}

Manuscript received: 23 February 2021. Revision accepted: 27 July 2021.

\begin{abstract}
Hidayat A, Rahayu ES, Abdullah M, Retnoningsih A. 2021. Microsatellites to reveal genetic diversity and to distinguish four mangoes of Tegal District, Central Java, Indonesia. Biodiversitas 22: 3467-3473. The Wirasangka mango is Tegal District's flora of identity, which requires recognition, and its existence deserves to be preserved. However, based on the morphology of the fruit, most of the people of Tegal still have difficulty distinguishing the wirasangka mango from other mangoes. Molecular markers are needed to ascertain the differences between these mango varieties. Microsatellite DNA is a repeating DNA of stable DNA markers with high repeatability and polymorphism. This study analyzes the level of genetic diversity and microsatellite alleles that can differentiate four mangoes from Tegal District, Central Java, Indonesia, i.e. wirasangka, tengkueh, golek, and okyong. Eleven accessions of six locations in Tegal District were analyzed using ten microsatellite loci. The microsatellite amplification result was separated using electrophoresis in $6 \%$ polyacrylamide gel and then visualized with silver dye. A total of 35 microsatellite alleles were found measuring 100-1000 bp, ranging from 1-7 alleles for each locus. The average polymorphism information content (PIC) of 0.54 indicates that genetic diversity is relatively high and informative. Therefore, the microsatellite alleles can be used to differentiate mango varieties. The specific allele characteristic of wirasangka mango accession is locus AJ63516, with an allele size of 600-700bp.
\end{abstract}

Keywords: Flora of identity, genetic diversity, microsatellite, Tegal's mangoes, wirasangka

\section{INTRODUCTION}

Mango (Mangifera indica Linn.) is an introduced crop and a major agricultural in Indonesia (Arifin 2013; Sulistyowati et al. 2015). Mango metabolism in the leaves, stems, flowers of mangoes and other organs has adapted to tropical conditions (Ramirez and Davenport 2010; Yahia 2011; Wang 2020). Therefore, mangoes can be cultivated in almost all parts of Indonesia. Mangoes have high genetic diversity with a complex history of domestication through various innovative modern breeding techniques (Warschefsky and von Wettberg 2019). Many "new" mango varieties are given unique names, particularly in Indonesia (Gajanana et al. 2015; Rahman 2020). The genetic diversity of mangoes in Indonesia is very high; Eighty-two mango varieties that have been using morphological and molecular markers show a similarity coefficient of 0.12-0.40 (Fitmawati et al. 2010). The study of genetic diversity used isozyme (Majumder et al. 2012), physicochemical (Akin-Idowu et al. 2020), random amplified polymorphic DNA (RAPD), minisatellite DNA (Srivastava et al. 2012), inter simple sequence repeat (Gajera et al. 2011; Archak et al. 2014), and microsatellite (Ravishankar et al. 2011) show that mangoes have high diversity both at the species and infraspecies. Indonesia and Malaysia also have several types of wild mangoes (Singh et al. 2016). These wild types are vital to support mango breeding programs (Zhang et al. 2020).

The Tegal District, Central Java, has designated the Wirasangka mango variety as the flora of the region's identity. This variety has been legalized by Pusat Perlindungan Varietas Tanaman dan Perijinan Pertanian Departemen Pertanian (PPVT-PP 2017). The superiority of wirasangka mango are fragrant aroma, fresh sweet taste, soft texture, thick fruit flesh, and long-stored (Rahayu and Bodijantoro 2017) and can become a superior economic commodity as fresh fruit or processed products. The PPVTPP Institute in 2017 identified the morphology and agronomy of wirasangka mangoes, but some of them differ from the results of Rahayu's (2018) observation. Therefore, the identity of mangoes needs to be verified using more accurate techniques such as molecular markers. A stable identity determines mango status' certainty to be conserved and developed into a true-to-type potential commodity.

The problem is that wirasangka mangoes population in the Tegal region is deficient, with about 50 trees. The mango population in Tegal District needs to be increased so that its existence is sustainable. Efforts to increase the population can be made through vegetative propagation so that in a relatively short time, the number of plants would increase significantly. The problem at hand is the unclear parent of the wirasangka variety. To date, Tegal people have found it difficult to distinguish the wirasangka mango from other mangoes in the area, such as tengkueh, golek, and okyong. The morphological characteristics of the four mangoes are highly similar. Their fruits have a common characteristic of 'oval shape' (Figure 1), with similar tastes and difficult to distinguish (Rahayu and Bodijantoro 2017).

Morphological and agronomic characteristics are easily influenced by environmental changes (Majumder et al. 
2012). Genetic profiles' differences using molecular markers will facilitate obtaining mango identities (Begum et al. 2013). M. indica can also be recognized by the fruit aroma of its close relatives, such as the musk mango $(M$. casturi), kweni mango (M. odorata), and pakel mango ( $M$. foetida). Aromatic compounds that affect mangoes' taste are terpenic hydrocarbons, namely $\alpha$-pinene, $\beta$-myrcene, and $\beta$-caryophyllene (Asif et al. 2016; Li et al. 2017). In addition, Mangiferin compounds (xanthones C-glycoside) are found in the bark and young leaves (Barreto et al. 2008; Ramírez et al. 2016); therefore, such organs also have a distinctive aroma for each species. The aroma between mango species is relatively easy to distinguish, but the aroma among varieties of the same mango species is difficult to differentiate (Rahman 2020).

A high and reproducible microsatellite polymorphism is a valuable marker for analyzing genetic profiles (Ariffin et al. 2015). Microsatellites have also shown compatibility with other species in the genus Mangifera. It means that microsatellites are abundant in mango relatives' genomes, essential to support variety protection efforts (Ravishankar et al. 2011). Microsatellite alleles have been shown to distinguish mangoes with highly similar phenotypes (Umar et al. 2013). Besides morphological and agronomic characters, heterozygosity values are also crucial for mango breeding programs (Surapaneni et al. 2013).

Microsatellite markers have been reported to be effective for identifying mangoes. Microsatellite studies of mango varieties in Thailand produced 78 alleles, more than $80 \%$ of which were polymorphic (Ganogpichayagrai et al. 2016). Research by Tasliah et al. (2016) on 161 accessions of mangoes produced 1006 alleles measuring 70-390 bps. Microsatellites are also effective for identifying 200 mango varieties in the Philippines (Sales and Butardo 2017), 12 local mangoes in Pakistan (Nazish et al. 2017), and 20 mango varieties in India (Ravishankar et al. 2017). It is, therefore, evident that this marker can reveal the differences in wirasangka mango varieties that have morphological and agronomic similarities to the tengkueh, golek, and okyong varieties. The purpose of this study was to uncover genetic diversity and to obtain microsatellite alleles that differentiate wirasangka mangoes from tengkueh, golek, and okyong.

\section{MATERIALS AND METHODS}

We conducted this research at the Biology Laboratory, Faculty of Mathematics and Natural Sciences, Universitas Negeri Semarang, and the Perhutani Cepu Research and Development Center, Central Java, Indonesia from March to October 2019. The mango varieties studied consisted of 11 trees recognized as wirasangka, tengkueh, golek, and okyong varieties (Figure 1) in six Tegal District, Central Java, Indonesia locations (Procot, Kramat, Pangkah, Talang, Lebaksiu, and Kedungbanteng) (Figure 2). The wirasangka mango tree in Procot is a single mother tree (SMT) identified by The Department of Agriculture and Food Security of Tegal District based on morphological and agronomic traits.
Mango genomic DNA was isolated from leaves using Solikin et al. (2017) method. The genomic DNA was then amplified at ten microsatellite loci. DNA amplification was carried out using a peqSTAR $2 X$ Thermocycler machine. The locus, sequence, and temperature melting (TM) of each microsatellite primer are presented in Table 1.

The PCR formulation consisted of $10 \mu$ Dream Taq, 2 $\mu \mathrm{l}$ Forward Primer, $2 \mu \mathrm{l}$ Reverse Primer, $2 \mu \mathrm{l}$ DNA isolate with $30 \mathrm{ng} / \mu \mathrm{l}$ DNA concentration and $4 \mu \mathrm{lddH} 2 \mathrm{O}$. The PCR stages consisted of pre-denaturation for 3 minutes at $95^{\circ} \mathrm{C}$, denaturation for 30 seconds at $95^{\circ} \mathrm{C}$, annealing for 30 seconds at an optimal temperature according to primer, and extension 1 minutes at $72^{\circ} \mathrm{C}$. Denaturation, annealing, and extension were using 35 cycles. The microsatellite amplification products were electrophoresis with 1000 volt for approximately 1 hour 45 minutes in a $6 \%$ polyacrylamide gel. The gel was then stained using the silver staining method by Retnoningsih et al. (2010).

Microsatellite alleles are determined by the presence of bands on the polyacrylamide gel. We analyzed the number and size alleles to determine frequencies used to calculate the expected heterozygosity (He) and Polymorphism Information Content (PIC). The number and size of the resulting alleles also determined the heterozygosity (Ho) value obtained from each allele's observations. The values of $\mathrm{He}$ and $\mathrm{Ho}$ range from 0 (zero) to 1 (one). Ho values close to zero are low, while Ho values close to 1 are high (Liu and Chen 1998). The PIC value is used to describe allele polymorphisms that indicate the level of genetic diversity. The PIC value depends on the number and frequency of allele occurrences, so the PIC value determines the informativity level. Therefore, markers with high PIC values are valid for identifying and taxonomic studies.

A PIC value of more than 0.5 is highly informative, a PIC between 0.5 and 0.25 is moderate, and a PIC less than 0.25 is less informative (Botstein et al. 1980). Azmat et al. (2016) argue that a very informative primer has a value of $\geq 0.6$. Similarity analysis is presented in the form of a dendrogram, which is translated from a similarity matrix based on the unweighted pair group with arithmetical averages (UPGMA) of the NTSYS-pe program version 2.02 .

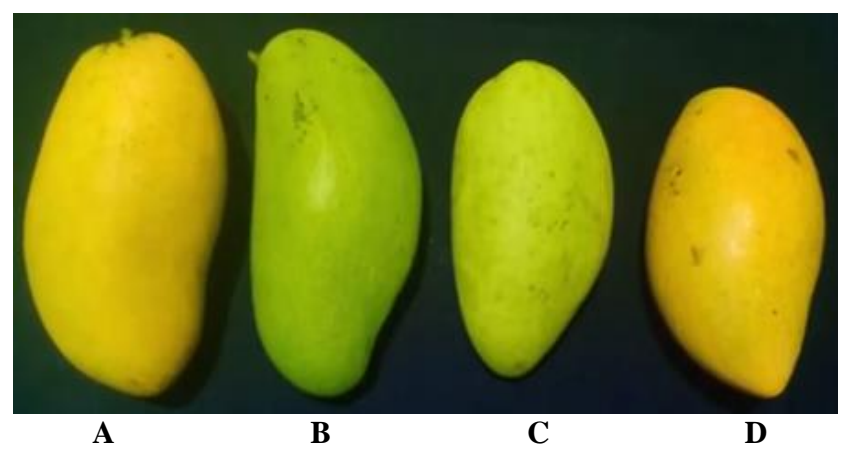

Figure 1. Tegal mangoes fruit: A. Wirasangka, B. Golek, C. Tengkueh, D. Okyong 

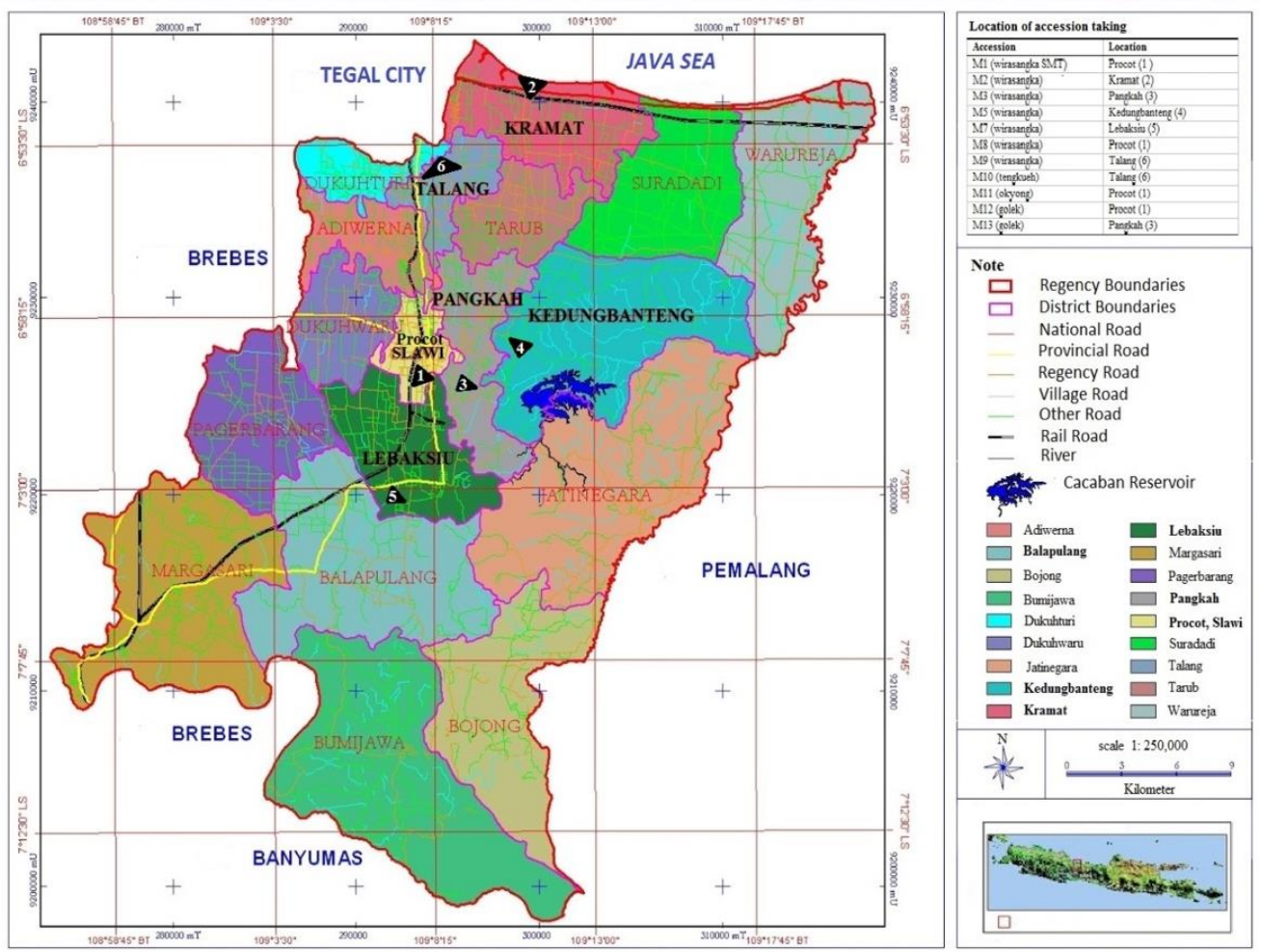

Figure 2. Collection sites of mango sample in Tegal District, Central Java, Indonesia

Table 1. Mango microsatellite primers

\begin{tabular}{|c|c|c|c|c|c|}
\hline Locus & & Primer sequence & Size range & $\mathbf{T M}$ & Source \\
\hline \multirow[t]{2}{*}{ QGMi018 } & F: & 5'-GCTCTCTCTGTAACCTTCTTGTTT-3' & $179-195$ & 56.9 & Nazish et al. (2017) \\
\hline & $\mathrm{R}:$ & 5'-GTTTCTTAGTTGTGTCCGTTGTTGCTG-3' & & & \\
\hline \multirow[t]{2}{*}{ QGMi011 } & F: & $5^{\prime}$-CAACTTCCGAAAGCTAGAGGAG-3' & $248-290$ & 48.8 & \\
\hline & $\mathrm{R}:$ & 5'-GTTTCTTCGTGGCACTCATTACCACAC-3' & & & \\
\hline \multirow[t]{2}{*}{ QGMi009 } & $\mathrm{F}:$ & 5'-GGGTTAGCAAAACTGGTGGA-3' & $156-228$ & 62.6 & \\
\hline & $\mathrm{R}:$ & 5'-GTTTCTTCCCCAAGGATATACAGTAACCAG-3' & & & \\
\hline \multirow[t]{2}{*}{ MiIIHR52 } & $\mathrm{F}:$ & $5^{\prime}$-CCCTCGCTTTGAATAATACCG-3' & $112-206$ & 54.1 & Ravishankar et al. (2017) \\
\hline & $\mathrm{R}:$ & $5^{\prime}$-TCAACACCGGACACATTGAT-3' & & & \\
\hline \multirow[t]{2}{*}{ MiIIHR55 } & $\mathrm{F}:$ & $5^{\prime}$-GGAGAGCTGAGAGGCCATAA-3' & $225-301$ & 59.8 & \\
\hline & $\mathrm{R}:$ & $5^{\prime}-\mathrm{CCACGAGACGACAGTCAAAA}-3^{\prime}$ & & & \\
\hline \multirow[t]{2}{*}{ MiIIHR68 } & $\mathrm{F}:$ & 5' -GGAAAGGGCTTGGTGTTGTA-3' & $161-222$ & 56.9 & \\
\hline & $\mathrm{R}:$ & $5^{\prime}$-CACTATCAACGCCTTCAGCA-3' & & & \\
\hline \multirow{2}{*}{ MiIIHR72 } & $\mathrm{F}:$ & $5^{\prime}$-CCGGGGGTTAGAATTACGAT-3' & $121-169$ & 56.9 & \\
\hline & $\mathrm{R}:$ & $5^{\prime}$-AAACCTTGGCCTTGGCTATT-3' & & & \\
\hline \multirow[t]{2}{*}{ AJ635166 } & $\mathrm{F}:$ & $5^{\prime}$-CTTGAAAGAGATTGAGATTG-3' & $81-336$ & 59.8 & Tasliah et al. (2016) \\
\hline & $\mathrm{R}:$ & $5^{\prime}$-AGAAGGCAGAAGGTTTAG-3' & & & \\
\hline \multirow[t]{2}{*}{ AJ938175 } & $\mathrm{F}:$ & 5'-GCTCTTTCCTTGACCTT-3' & $101-365$ & 48.8 & \\
\hline & $\mathrm{R}:$ & $5^{\prime}$-TCAAAATCGTGTCATTTC-3' & & & \\
\hline \multirow[t]{2}{*}{ AJ635165 } & F: & $5^{\prime}$-GATGAAACCAAAGAAGTCA-3' & $100-377$ & 59.8 & \\
\hline & $\mathrm{R}:$ & $5^{\prime}-$ CCAATAAGAACTCCAACC-3' & & & \\
\hline
\end{tabular}

\section{RESULTS AND DISCUSSION}

\section{Microsatellite analysis}

Identification results of wirasangka, tengkueh, golek, and okyong mangoes at ten microsatellite loci found 35 alleles with varying numbers of 1-7 alleles for each locus (Table 2). The calculation results show that the six microsatellite loci are highly informative, namely
QGMi018, QGMi011, MiIIHR68, MiIIHR72, AJ635166, and AJ635165; both AJ938175 and MiIIHR52 loci are moderately informative, while the other two loci are not informative. Analysis of the genetic diversity, allele frequency, and heterozygosities showed an average PIC value of 0.54 , revealing the significance of the genetic diversity level in the mango population. The PIC value also indicates the level of allele variation (Surapaneni et al. 
2013). The value is higher than the previous studies conducted by Razak et al. (2019), Begum et al. (2014), and Azam et al. (2019), but lower than the value obtained by Ravishankar et al. (2011). The difference in PIC values can be associated with differences in microsatellite allele profiles, the number of accessions studied, varieties, and locations (Surapaneni et al. 2013). The QGMi011 locus, which has the highest PIC and is very informative, strengthens the research results of Nazish et al. (2017). These loci that can differentiate mango varieties are mainly supported by the allele frequency values that vary from $0.088-0.206$. The six highly informative loci can be used as a reference for further mango research.

The genetic diversity of wirasangka, tengkueh, golek, and okyong mangoes is relatively high. The various mechanisms of mango pollination are strongly suspected of contributing to the high genetic diversity of M. mangifera. The mango has branched panicle flowers borne at the terminal shoots with male and hermaphrodite flowers (Sandip et al. 2015, Bally and Dillon 2018). Mango pollination can occur through two mechanisms: selfpollination and cross-pollination. The method of pollination determined the type of mango embryo produced. Cross-pollination produces monoembryonic mangoes, while self-pollination produces polyembryonic mangoes (Bally 2006). Cross-pollination between mango varieties produces pithy seeds that will grow into single, usual sprouts. Tegal's wirasangka mango seed partly has two sprouts and partly only one sprout. It shows that both pollination mechanisms occur in wirasangka mangoes, but the cross-pollination mechanism is more dominant.

The mango pollen is compatible for hybridization and fertilization intra and inter variety (Bally 2006; GehrkeVélez et al. 2012; Warschefsky and von Wettberg 2019). Microsatellite alleles variation arises due to the fusion of two genotypically different individuals. The desired genotype is generally maintained clonally and given a unique local name (Begum et al. 2013; Kuhn et al. 2017; Rahman 2020). Vegetative propagation is one of the genotype protection measures because gene flow does not occur.

Wirasangka SMT Procot and tengkueh mangoes have specific alleles at locus AJ635165 (Figure 3). These specific microsatellite alleles can be used as a molecular identity of the wirasangka mango claimed by PPVT-PP 2017. The wirasangka SMT mango has characterized fruit morphology. The fruit shape was not influenced by male parent pollen. Instead, the Mesocarpium part results from gene expression, which is part of the female parent determining the outer fruit shape (Bally 2006; Ahmed and Mohamed 2015; Ramírez et al. 2016; Dautt-Castro et al. 2018). This statement confirms that fruit morphology can be the main differentiator of mango varieties. However, the fruit, leaf, and canopy shape of wirasangka mango have a highly similar morphology to the varieties of tengkueh, golek, and okyong (Abdullah et al. 2020), so finding specific alleles will help to ensure that wirasangka mangoes will be the source of the entries.

Based on the dendrogram results of the similarity analysis of wirasangka mango, tengkueh, golek, and okyong are presented in Figure 4, wirasangka mangoes are in two different groups. Wirasangka of the SMT Procot, Pangkah, Talang, Kedungbanteng, Golek Pangkah, Golek Procot, and Okyong Procot are in group I, while wirasangka Procot, non SMT, Kramat, Lebaksiu and Tengkueh Talang are in group II. The dendrogram shows that the 11 mangoes analyzed have a similarity coefficient of 0.46-0.91. Wirasangka Talang mango is most similar to SMT Procot, as well as wirasangka Pangkah and Kedungbanteng mangoes.

The results of interviews with farmers stated that the mango wirasangka Talang, Pangkah, and Kedungbanteng were the result of grafting using scion from trees derived from the germination of wirasangka SMT Procot mango seeds. The difference in microsatellite alleles found of these four wirasangka mangoes is because each seed carries a different genotype according to the pollen's origin. Most of these seeds have been distributed to the Tegal community to increase the wirasangka populations. These mango trees were used as a source of rootstock and scion in grafting. Mango trees from cross-pollinated seeds are known to have weaker roots than trees of self-pollination seeds (Srivastav et al. 2014; El-Habashy et al. 2016). Therefore, mango seeds from self-pollination have a more robust stem and root compactness, so they are suitable as rootstocks (Bally and Dillon 2018). Grafting is the proper propagation technique for strong mango roots.

Table 2. Allele frequencies, observed heterozygosity, expected heterozygosity, and PIC of wirasangka, tengkueh, golek, and okyong mangoes

\begin{tabular}{ccccccc}
\hline Locus & Relative size (bp) & Number of alleles & Allele frequencies & Ho & He & PIC \\
\hline QGMi018 & $250-1000$ & 3 & $0.231-0.461$ & 0.360 & 0.688 & $\mathbf{0 . 6 4 0}$ \\
QGMi011 & $200-900$ & 7 & $0.088-0.206$ & 0.158 & 0.882 & $\mathbf{0 . 8 4 2}$ \\
QGMi009 & $100-150$ & 1 & 1,000 & 1,000 & 0.000 & 0.000 \\
MiIIHR52 & $200-700$ & 2 & $0.400-0.600$ & 0.520 & 0.503 & 0.480 \\
MiIIHR55 & $250-300$ & 1 & 1,000 & 1,000 & 0.000 & 0.000 \\
MiIIHR68 & $200-400$ & 5 & $0.154-0.384$ & 0.243 & 0.793 & $\mathbf{0 . 7 5 7}$ \\
MiIIHR72 & $150-250$ & 4 & $0.167-0.333$ & 0.278 & 0.756 & $\mathbf{0 . 7 2 2}$ \\
AJ635166 & $300-500$ & 3 & $0.300-0.400$ & 0.340 & 0.691 & $\mathbf{0 . 6 6 0}$ \\
AJ938175 & $400-500$ & 2 & 0.500 & 0.500 & 0.524 & $\mathbf{0 . 5 0 0}$ \\
AJ635165 & $500-700$ & 7 & $0.038-0.308$ & 0.202 & 0.836 & $\mathbf{0 . 7 9 8}$ \\
Total & & 35 & & 4,601 & 5,673 & 5,399 \\
Average & & 3,5 & & 0.460 & 0.567 & $\mathbf{0 . 5 3 9}$ \\
\hline
\end{tabular}




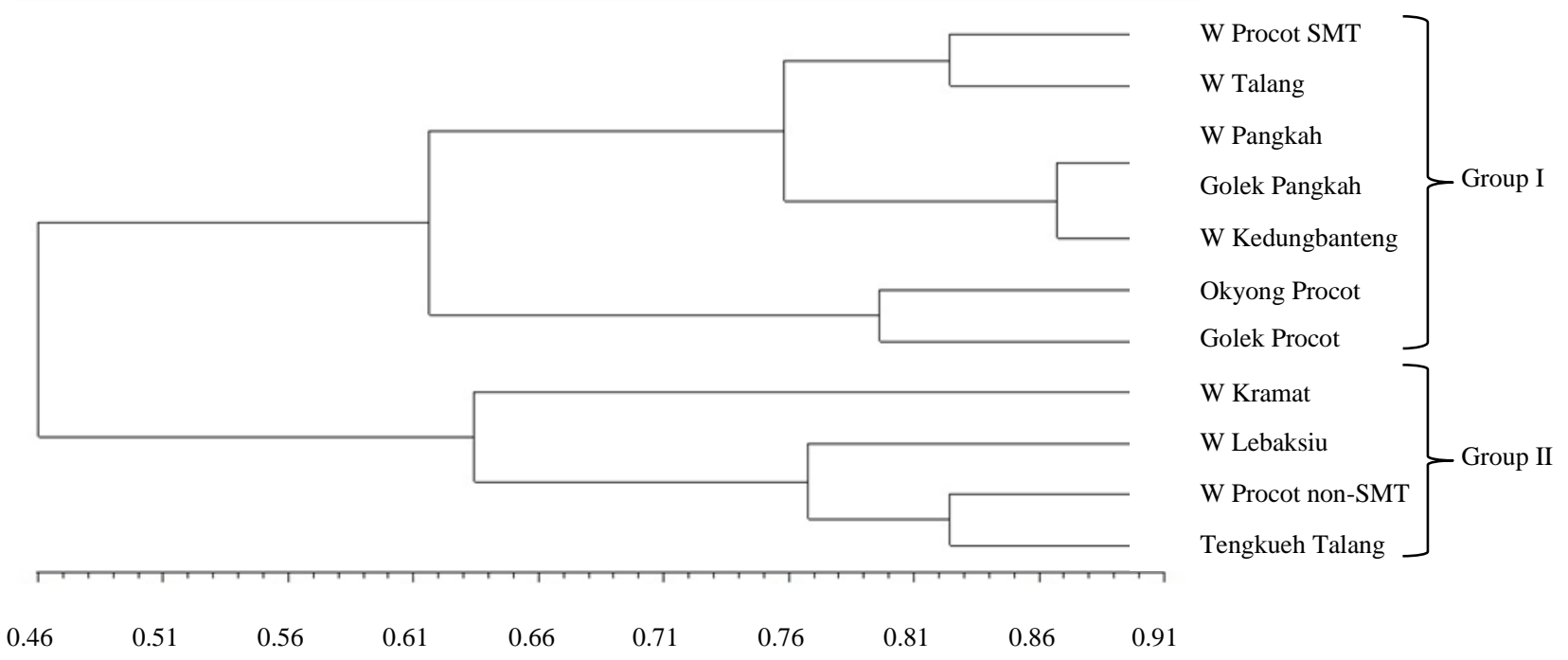

Figure 4. Dendrogram of Tegal's mango varieties developed using similarity coefficient from 0.46 to 0.91

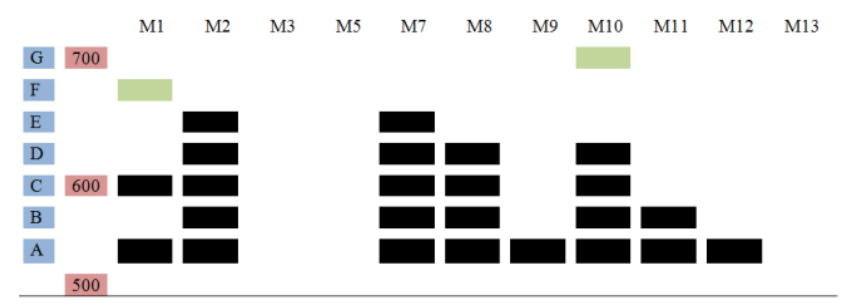

Figure 3. Projection of Locus AJ635165 Microsatellite Alleles Visualization. Note: black $=$ allele detected , red $=100$ bp DNA ladder, green $=$ specific allele

The golek and okyong mangoes group I are similar to wirasangka SMT of Procot. The okyong is an introduced variety from Thailand, known as okrong or nam dok mai, while the golek of Procot comes from India. The wirasangka SMT in Procot is thought to have originated from natural or artificial cross-pollination with the introduced varieties. Group II consisted of mangoes of Kramat, Lebaksiu, Procot non-SMT, and tengkueh Talang. Wirasangka Procot, which is not SMT and Lebaksiu, is derived from seed germination, possibly crossbreeding with other mango varieties, such as the arum manis. The wirasangka Kramat mango is known as the result of grafting with the scion wirasangka mango from crossing. Tengkueh mango is another variety that has a fruit shape almost similar to wirasangka. The Talang people say that the wirasangka mango is a synonym with tengkueh mango. Group II's four mango varieties were thought to have originated from the seeds of the same female parent, but it experiences random crosses. The other wirasangka mango (except SMT) is not suitable to be categorized as wirasangka, but it is the progenies of wirasangka, which can be considered a new variety from open pollination.

The finding of the specific allele of SMT Procot mango, which has superior characteristics as identified by Rahayu
\& Bodijantoro (2017), can be used as a marker to ensure the correctness of scion. Grafting can improve the seedling quality with better root quality. The superiority of wirasangka SMT of Procot needs to be maintained using the proper propagation or breeding technique so that consumers get quality fruit and farmers can carry out cultivation efficiently (Sivakumar et al. 2011; Warschefsky and von Wettberg 2019; Wang 2020).

\section{ACKNOWLEDGEMENTS}

We thank the Indonesian Ministry of Research and Technology/National Research and Innovation Agency (RISTEK-BRIN) for funding this research. We would also like to thank the Perhutani Cepu Research and Development Center technicians, Central Java, for their assistance during the research data collection process.

\section{REFERENCES}

Abdullah M, Rahayu ES, Retnoningsih A. 2020. Morphological characterization and its variation of "Wirasangka" mango as the flora identity of Tegal District, Central Java, Indonesia. J Phys Conf Ser 1567 (3): 032062. DOI: 10.1088/1742-6596/1567/3/032062.

Ahmed THM, Mohamed ZMA. 2015. Diversity of Mango (Mangifera indica L.) cultivars in Shendi area: Morphological fruit characterization. Int J Res Agric Sci 2 (4): 2348-3997.

Akin-Idowu PE, Adebo UG, Egbekunle KO, Olagunju YO, Aderonmu OI, Aduloju AO. 2020. Diversity of Mango (Mangifera Indica L.) Cultivars Based on Physicochemical, Nutritional, Antioxidant, and Phytochemical Traits in southwest Nigeria. Intl J Fruit Sci 20 (suppl.2): S352-S376.

Archak S, Gaikwad AB, Gautam D. 2014. Molecular genetic diversity analysis of commercial mango (Mangifera indica L.) cultivars employed as parents in hybrid development in India. Indian J Plant Gen Res 27: 209-216. DOI: 10.5958/0976-1926.2014.00016.3.

Ariffin Z, Sah MSM, Idris S, Hashim N. 2015. Genetic diversity of selected Mangifera species revealed by inter simple sequence repeats markers. Intl J Biodiver 2015: 458237. DOI: 10.1155/2015/458237. 
Arifin B. 2013. On the competitiveness and sustainability of the Indonesian agricultural export commodities. ASEAN J Econ Manag Account 1 (1): 81-100: 81-100.

Asif A, Farooq U, Akram K, Hayat Z, Shafi A, Sarfraz F, Aftab S. 2016. Therapeutic potentials of bioactive compounds from mango fruit wastes. Trends Food Sci Technol 53: 102-112. DOI: 10.1016/j.tifs.2016.05.004.

Azam K, Mir H, Prasad BD, Ahmed F, Kumari A, Sinha A. 2019. Microsatellite marker-based characterization of mango cultivars Indian J Hortic 76 (4): 561-565. DOI: 10.5958/09740112.2019.00091.4.

Azmat MA, Khan AA, Khan IA, Rajwana IA, Cheema HMN, Khan AS 2016. Morphological characterization and SSR-based DNA fingerprinting of elite commercial mango cultivars. Pak J Agric Sci 53 (2): 321-330. DOI: 10.21162/PAKJAS/16.2988.

Bally IS, Dillon NL. 2018. Mango (Mangifera indica L.) Breeding. In Advances in Plant Breeding Strategies: Fruits. Springer, Cham.

Bally IS. 2006. Mangifera indica (mango). Species Profiles for Pacific Island Agroforestry. Permanent Agriculture Resources, Hawai'i.

Barreto JC, Trevisan MTS, Hull WE, Erben G, De Brito ES, Pfundstein B, Würtele G, Spiegelhalder B, Owen RW. 2008. Characterization and quantitation of polyphenolic compounds in bark, kernel, leaves, and peel of mango (Mangifera indica L.). J Agric Food Chem 56 (14) 5599-5610. DOI: 10.1021/jf800738r

Begum H, Reddy MT, Malathi S, Reddy BP, Narshimulu G, Nagaraju J, Siddiq EA. 2014. Morphological and microsatellite analysis of intravarietal heterogeneity in 'Beneshan'mango (Mangifera indica L.). Intl J Agric Food Res 1 (1): 1-18. DOI: 10.24102/ijafr.v3i2.498.

Botstein D, Whie RL, Skolnick M, Davis RW. 1980. Construction of a genetic linkage map in man using restriction fragment length polymorphisms. Am J Hum Genet 32: 314-331.

Dautt-Castro M, Ochoa-Leyva A, Contreras-Vergara CA, MuhliaAlmazán A, Rivera-Domínguez M, Casas-Flores S, Martinez-Tellez MA, Sañudo-Barajas A, Osuna-Enciso T, Baez-Sañudo MA, QuirozFigueroa FR, Kuhn DN, Islas-Osuna MA. 2018. Mesocarp RNA-Seq analysis of mango (Mangifera indica L.) identify quarantine postharvest treatment effects on gene expression. Sci Hortic 227: 146153. DOI: $10.1016 /$ j.scienta.2017.09.031

El-Habashy S, Maklad MF, Ahmed EA. 2016. Effect of self and crosspollination in some local mango cultivars on fruit set and retained fruits. American-Eurasian J Agric Environ Sci 16 (12): 1776-1783. DOI: 10.5829/idosi.aejaes.2016.1776.1783.

Fitmawati, Hartana A, Purwoko BS. 2010. Diversity of Indonesian mango (Mangifera indica) cultivars based on morphological and RAPD markers. SABRAO J Breed Genet 42 (2): 84-95.

Gajanana TM, Dinesh MR, Rajan S, Vasudeva R, Kumar SS, Lamers HA, Ramanatha RV. 2015. Motivation for on-farm conservation of mango (Mangifera indica) diversity in India-A case study. Indian J Plant Genet Resour 28 (1): 1-6. DOI: 10.5958/0976-1926.2015.00001.7.

Gajera HP, Tomar RS, Patel SV, Viradia RR, Golakiya BA. 2011 Comparison of RAPD and ISSR markers for genetic diversity analysis among different endangered Mangifera indica genotypes of Indian Gir forest region. J Plant Biochem Biotechnol 20 (2): 217-223. DOI: $10.1007 / \mathrm{s} 13562-011-0049-2$

Ganogpichayagrai A, Rungsihirunrat K, Palanuvej C, Ruangrungsi N. 2016. Characterization of Mangifera indica cultivars in Thailand based on macroscopic, microscopic, and genetic characters. J Adv Pharm Technol Res 7 (4): 127. DOI: 10.4103/2231-4040.191419.

Gehrke-Vélez M, Castillo-Vera A, Ruiz-Bello C, Moreno-Martinez JL, Moreno-Basurto G. 2012. Delayed self-incompatibility causes morphological alterations and crop reduction in 'Ataúlfo'mango (Mangifera indica L.). NZ J Crop Hortic Sci 40 (4): 215-227.

Kuhn DN, Bally IS, Dillon NL, Innes D, Groh AM, Rahaman J, Ophir R, Cohen Y, Sherman A. 2017. Genetic map of mango: a tool for mango breeding. Front Plant Sci 8: 577. DOI: 10.3389/fpls.2017.00577.

Li L, Ma XW, Zhan RL, Wu HX, Yao QS, Xu WT, Luo C, Zhou YG, Qing-Zhi Liang QZ, Wang SB. 2017. Profiling of volatile fragrant components in a mini-core collection of mango germplasms from seven countries. PLoS One 12 (12): e0187487. DOI 10.1371/journal.pone.0187487.

Liu JS, Chen R. 1998. Sequential Monte Carlo methods for dynamic systems. J Amer Stat Assoc 93 (443): 1032-1044.

Majumder DAN, Hassan L, Rahim MA, Kabir MM. 2012. Genotypic and phenotypic variability in mango (Mangifera indica $\mathrm{L}$.). Bangladesh $\mathrm{J}$ Agric Res 37 (4): 683-690. DOI: 10.3329/bjar.v37i4.14393.
Nazish T, Shabbir G, Ali A, Sami-ul-Allah S, Naeem M, Javed M, Seher R. 2017. Molecular diversity of Pakistani mango (Mangifera indica L.) varieties based on microsatellite markers. Genet Mol Res 16 (2): gmr16029560. DOI: $10.4238 /$ gmr16029560.

Rahayu ES, Bodijantoro FPM, 2017. Monograf: Flora Identitas Kota/Kabupaten di Jawa Tengah: Karakteristik dan Kuantitas Populasinya. FMIPA UNNES, Semarang. [Indonesian]

Rahman NIZ. 2020. Relasi sematik pada penamaan jenis-jenis mangga di Indonesia. Kredo: Jurnal Ilmiah Bahasa dan Sastra 3 (2): 322-337. [Indonesian]

Ramírez F, Davenport TL. 2010. Mango (Mangifera indica L.) flowering physiology. Scientia Horticulturae 126 (2): 65-72.

Ramírez NM, Farias LM, Santana FA, Leite JPV, Dantas MIDS, Toledo RCL, De Queiroz JH, Martino HSD, Ribeiro SM, R. 2016. Extraction of mangiferin and chemical characterization and sensorial analysis of teas from Mangifera indica $\mathrm{L}$. leaves of the Ubá variety. Beverages 2: 33. DOI: $10.3390 /$ beverages2040033.

Ravishankar KV, Mani BHR, Anand L, Dinesh MR. 2011. Development of new microsatellite markers from Mango (Mangifera indica) and cross-species amplification. Am J Bot 98 (4): e96-e99. DOI: 10.3732/ajb. 1000263

Ravishankar KV, Padmakar B, Lavanya B, Mani BH, Dinesh MR. 2017. Development and characterization of microsatellite loci from mango (Mangifera indica L.). Indian J Biotechnol 1 (6): 250-253.

Razak SA, Azman NHEN, Ismail SN, Yusof MFM, Ariffin MAT, Sabdin ZHM, Abdullah N. 2019. Assessment of diversity and population structure of mango ('Mangifera indica' $\mathrm{L}$.) germplasm based on microsatellite (SSR) markers. Austr J Crop Sci 13 (2): 315

Retnoningsih A, Megia R, Hartana A. 2010. Characterization and evaluation of Musa acuminata cultivars in Indonesia based on microsatellite markers. Floribunda 4 (1): 21-32.

Sales EK, Butardo NG. 2017. SSR markers for mango (Mangifera indica L.) cultivar identification and genetic characterization. Philippine $\mathbf{J}$ Crop Sci 42 (3): 30-38.

Sandip M, Makwana AN, Barad AV, Nawade BD. 2015. Physiology of flowering-the case of mango. Int J Appl Res 1 (11): 1008-1012.

Singh NK, Mahato AK, Jayaswal PK, Singh A, Singh S, Singh N, Rai V, SV AM, Gaikwad K, Sharma N, Lal S, Srivastava M, Prakash J, Kalidindi U, Singh SK, Singh AK, Khan K, Mishra RK, Rajan S, Bajpai A, Sandhya BS, Nischita P, Ravishankar KV, Dinesh MR, Kumar N, Jaiswal S, Iquebal MA, Kumar D, Rai A, Sharma TR. 2016. Origin, diversity, and genome sequence of mango (Mangifera $\begin{array}{lllll}\text { indica L.). Indian J History Sci } 51 & (2.2) \text { DOI: }\end{array}$ 10.16943/ijhs/2016/v51i2.2/48449

Sivakumar D, Jiang Y, Yahia EM. 2011. Maintaining mango (Mangifera indica L.) fruit quality during the export chain. Food Res Intl 44 (5): 1254-1263. DOI: 10.1016/j.foodres.2010.11.022.

Solikin A, Retnoningsih A, Rahayu ES. 2017. Karakterisasi aksesi durian lokal koleksi Hortimart Agro Centre Jawa Tengah menggunakan penanda molekuler inter simple sequence repeat (ISSR). Floribunda 5 (7): 267-276. [Indonesian]

Srivastav M, Singh AK, Dubey AK, Bhagat SK. 2014. Effect of self-, open-and cross-pollination with Sensation on fruit set in mango cultivar Amrapali. Indian J Hortic 71 (3): 412-414.

Srivastava N, Bajpai A, Chandra R, Rajan S, Muthukumar M, Srivastava MK. 2012. Comparison of PCR-based marker systems for genetic analysis in different cultivars of mango. J Environ Biol 33 (2): 159

Sulistyowati L, Natawidjaja RS, Rahmat B. 2015. Adoption of technology and economics efficiency of the small-holder mango farmers in Indonesia. Int J Appl Business Economic Res 13 (7): 4621-4645.

Surapaneni M, Vemireddy LR, Begum H, Reddy BP, Neetasri C, Nagaraju J, Siddiq EA. 2013. Population structure and genetic analysis of different utility types of mango (Mangifera indica L.) germplasm of Andhra Pradesh state of India using microsatellite markers. Plant Syst Evol 299 (7): 1215-1229. DOI: 10.1007/s00606013-0790-1.

Tasliah T, Karsinah K, Prasetiyono J. 2016. Keragaman sebelas klon mangga komersial Indonesia. Jurnal Hortikultura 26 (1): 31-40. [Indonesian]

Tasliah T, Rijzaani H, Hariyadi TZ, Yuriyah S, Rebin R, Cukurgondang KP, Silitonga TS. 2016. Analisis keragaman genetik 161 aksesi mangga Indonesia Menggunakan marka mikrosatelit. Jurnal AgroBiogen 9 (3): 125-134. [Indonesian]

Umar M, Ponnuswami M, Nagarajan P, Eyakumar P, Enthil S. 2013. Molecular characterization of ten mango cultivars using simple 
sequences repeat (SSR) markers. Afr J Biotechnol 12 (47): 6568 6573. DOI: 10.5897/AJB2013.12797.

Wang P, Luo Y, Huang J, Gao S, Zhu G, Dang Z, Gai J, Yang M, Zhu M, Zhang H, Ye X, Gao A, Tan X, Wang S, Wu S, Cahoon EB, Bai B, Zhao Z, Li Q, Wei J, Chen H, Luo R, Gong D, Tang K, Zhang B, N Z, Huang G, Hu S, Chen Y. 2020. The genome evolution and domestication of tropical fruit mango. Genome Biol 21 (1): 60. DOI: 10.1186/s13059-020-01959-8.

Warschefsky EJ, von Wettberg EJ. 2019. Population genomic analysis of mango (Mangifera indica) suggests a complex history of domestication. New Phytol 222 (4): 2023-2037. DOI: 10.1111/nph.15731.

Yahia EM. 2011. Mango (Mangifera indica L.). In: Postharvest Biology and Technology of Tropical and Subtropical Fruits. Woodhead Publishing, UK

Zhang C, Xie D, Bai T, Luo X, Zhang F, Ni Z, Chen Y. 2020. Diversity of a large collection of natural populations of mango (Mangifera indica Linn.) revealed by agro-morphological and quality traits. Diversity 12 (1): 27. DOI: $10.3390 / \mathrm{d} 12010027$. 